\title{
Call for a lighter regulatory burden on NIH researchers
}

[WASHINGTON] The US National Institutes of Health (NIH) should reduce the burden of federal regulations facing the universitybased and extramural scientists it funds, according to a report released last week.

The report, commissioned by the NIH at the request of Congress, calls for "concerted action and sustained attention," arguing that the rules are "in need of change, and in some cases, dramatic change".

According to the report, the burden of regulation should be reduced in the five areas it studied: conflict of interest, animal care and use, protection of human subjects, research integrity, and disposal of hazardous waste. It says that "all members of the community with whom these issues were discussed feel strongly, even passionately," about the need to address them, and quickly.

The report, NIH Initiative to Reduce Regulatory Burden, defines 'burden' as any aspect of a regulation that could be made more efficient without defeating its purpose. It was drawn up by John Mahoney, a management consultant and former NIH chief financial officer.

The report calls on the NIH to appoint a single individual or office (separate from the offices that now enforce the regulations) to coordinate a response, guided by advisers from the research community.

Anthony Demsey, a senior policy adviser in NIH's Office of Extramural Research, calls the report "well considered" and says the NIH is "very supportive" of many of the recommendations, and wants to "address right away some of the very clear issues".

But "there are others that may be controversial," he adds. "Obviously we reserve the right to consider not just the report but the comments we get as to how we want to go about the implementation." Demsey concedes that some interested groups, such as the Humane Society, did not have active input into the report, but that the NIH will "welcome" their response.

Scientists are beset by problems in all five areas, the report notes: rigid regulations that do not allow flexible responses; rules imposed by multiple agencies with inconsistent requirements; oversight by non-scientists; and poor communications with government agencies.

But it warns against over-hasty attempts

\section{US quest for ADS vaccine appoints a leader}

[WASHNGTON] After an 18-month search, the National Institutes of Health $(\mathrm{NH})$ announced last week that Gary Nabel, a professor of internal medicine and biological chemistry at the University of Michigan at Ann Arbor, is to become director of its new Vaccine Research Center.

In a statement, President

Bill Clinton said that Nabel will be an "incredible" asset in the search for an ADS vaccine - the centre's top priority. When he announced the creation of the centre in May 1997, Clinton called for the development of an ADS vaccine within a decade (see Nature 387, 323; 1997).

The time it took to appoint a director has been criticized by activists such as Gregg Gonsalves, policy director at the Treatment Action Group, which lobbies for ADS research. Also criticized is that Nabel, who developed the first gene

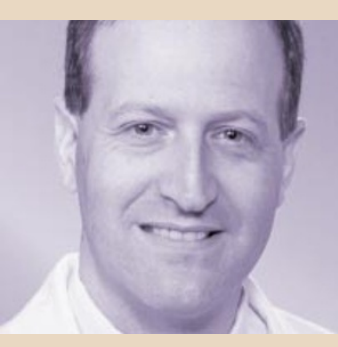

Nabel: wants a more scientific approach to vaccine research.

therapy for HIV infection and has developed DNA-based vaccines for melanoma and Ebola virus, is not an experienced vaccinologist or immunologist.

But $\mathrm{NHH}$ director Harold Varmus described Nabel as "a superb scientist" who is "remarkably well prepared" for the job. And David Baltimore, president of the California Institute of Technology and head of NIH's Aids Vaccine Research Committee - and under whom Nabel has worked calls the appointment "great".
Nabel told Nature that he plans to develop a broad scientific understanding of immune responses to foreign proteins, allowing predictions of a candidate vaccine's effectiveness, as opposed to randomly picking candidates and hoping for the best. He also plans to stress the development of candidate vaccines to fill what is currently a nearly empty pipeline for phase-one clinical trials, and to work closely with industry.

His scientific priorities include assessing whether a successful vaccine can be developed using cytolytic Tcell immunity, and developing approaches that enhance the production of neutralizing antibodies.

Nabel says he believes that his strengths do lie in vaccinology and immunology. "What I have not done is work in industry on vaccine development."

M. W. to undo regulations, which often result from careful political compromises. It cautions that, without careful planning, amendments could leave researchers worse off.

Instead, it says, NIH should seek help from allies in Congress and the administration, such as the White House's Office of Science and Technology Policy, to gauge the climate for change. But it adds that now is as good a time as any to try for change.

Congress asked NIH to streamline regulations affecting its extramural scientists when it approved its funding in 1998. Mahoney, charged with consulting researchers, interviewed officials at seven federal agencies and departments, eight universities and 11 research organizations, and enlisted 50 extramural scientists and officials in working groups that studied the five areas.

Congressman Dan Miller (Republican, Florida), who inserted the provision in the spending law, says he is "pleased" that NIH has documented the "excessive waste" caused by regulations.

The report is an encyclopedia of the rules' apparent redundancy, rigidity and inappropriateness. For example, scientists must answer to three different sets of animal-care inspectors, with site visits at least three times a year, and consequent paperwork.

It also says that allowing an animal to be used in surgery only once may be increasing the number used in research. And it points out that the cage-size requirements of the US Department of Agriculture force scientists to keep social animals, particularly primates, in solitary conditions - a policy the National Research Council has called "indefensible".

The report also cites an "exceedingly and needlessly legalistic and complex" process by which institutions assure the NIH that they are complying with protections for human subjects.

In addition, the report calls for the Office of Research Integrity in the Department of Health and Human Services to be restricted to an educational function. It argues that the office's authority to reinvestigate scientific misconduct cases after the institution involved has already done so is duplicative and leads to "second-guessing" of the original findings, compromising their authority.

Regarding conflict of interest, the report argues that Public Health Service regulations trigger "an excessive number" of disclosures because of an unrealistically low equity threshold of $\$ 10,000$, or 5 per cent ownership of entities that could be affected by a scientist's research.

On hazardous waste disposal, the report says universities are burdened by regulations intended to apply to industrial waste, not the small volumes produced by laboratories.

The report can be found at http:// www.nih.gov/grants/policy/regulatoryburden/. NIH is accepting comments for 30 days at regburd@od.nih.gov.

MeredithWadman 